\title{
Testicularis adrenalis rest tumor a congenitalis adrenalis hyperplasia hátterében
}

\author{
Brzózka Ádám dr. ${ }^{1}$ - Kuthi Levente dr. ${ }^{2}$ - Hajdú Erzsébet dr. ${ }^{3}$ \\ Magony Sándor dr. ${ }^{4}$ - Király István Előd dr. ${ }^{3}$ \\ Kincses Zsigmond Tamás dr. ${ }^{1}$ - Szatmári Angelika ${ }^{5}$ \\ Szalma Emese oh. - Palkó András dr. ${ }^{1}$ - Fejes Zsuzsanna dr. ${ }^{1,6}$ \\ 'Szegedi Tudományegyetem, Általános Orvostudományi Kar, Radiológiai Klinika, Szeged \\ ${ }^{2}$ Szegedi Tudományegyetem, Általános Orvostudományi Kar, Pathologiai Intézet, Szeged \\ ${ }^{3}$ Szegedi Tudományegyetem, Általános Orvostudományi Kar, Urológiai Klinika, Szeged \\ ${ }^{4}$ Szegedi Tudományegyetem, Általános Orvostudományi Kar, I. Belgyógyászati Klinika, Szeged \\ ${ }^{5}$ Szegedi Tudományegyetem, Egészségtudományi és Szociális Képzési Kar, Szeged \\ ${ }^{6}$ Affidea Diagnosztika, Szeged
}

\begin{abstract}
A congenitalis adrenalis hyperplasia különféle megjelenési formáiban a testicularis adrenalis rest tumorok prevalenciája eltérő. A tapintható, általában kétoldali hereelváltozás az esetek 90-95\%-ában a 21 -hidroxiláz enzim hiánya okozta mellékvesekéreg-hyperplasia következményeként jelenik meg. Az adrenalis rest tumorok, bár jól ismert elváltozások, diagnózisuk és kezelésük multidiszciplináris megközelítést igényel. Az endokrinológiai, urológiai, patológiai és radiológiai szakmák együttmúködése kiemelkedően fontos. Amennyiben korai stádiumban felismerésre kerül, adekvát szteroidhormon-emelés segíthet a térfoglalás méretének csökkentésében. Késői felismerés esetén azonban irrevezibilis károsodás jön létre, mely infertilitáshoz vezet. Mivel a kezelés az egyéb jó- és rosszindulatú hereelváltozásokhoz képest jelentősen különbözik, fontos a korai és pontos diagnózis felállítása. Esetismertetésünk kapcsán a testicularis adrenalis rest tumorok differenciáldiagnoszikai és kezelési nehézségeit multidiszciplináris szemszögből mutatjuk be.
\end{abstract}

Orv Hetil. 2020; 161(16): 623-631.

Kulcsszavak: testicularis adrenalis rest tumor, férfieredetű meddőség

\section{Testicular adrenal rest tumor in the background of congenital adrenal hyperplasia}

The prevalence of testicular adrenal rest tumours varies in different forms of congenital adrenal hyperplasia. Patients with 21-hydroxilase deficiency usually have bilateral and palpable testicular nodules. Although adrenal rest tumours are well documented in the literature, the diagnosis and management require a multidisciplinary approach: the cooperative work of endocrinologists, urologists, pathologists and radiologists is essential. In the case of an early diagnosis, appropriately increased corticosteroid treatment may reduce the tumour mass. In advanced stages, tumours can lead to irreversible parenchymal damage causing infertility. The importance of an early and accurate diagnosis cannot be emphasized enough, since the therapy differs significantly from other benign or malignant testicular neoplasia. A case of a testicular adrenal rest tumour is presented along with the multidisciplinary perspectives of the diagnosis and management of these lesions.

Keywords: testicular adrenal rest tumour, male infertility

Brzózka Á, Kuthi L, Hajdú E, Magony S, Király IE, Kincses ZsT, Szatmári A, Szalma E, Palkó A, Fejes Zs. [Testicular adrenal rest tumor in the background of congenital adrenal hyperplasia]. Orv Hetil. 2020; 161(16): 623-631.

(Beérkezett: 2019. november 30.; elfogadva: 2020. január 18.) 


\section{Rövidítések}

4Dion $=$ androszténdion; ACTH $=($ adrenocorticotropic hor mone) adrenokortikotrop hormon; anti-TPO = thyreoideaperoxidáz elleni antitest; $\mathrm{AR}=$ androgénreceptor; $\mathrm{CAH}=$ congenitalis adrenalis hyperplasia; $\mathrm{CRH}=($ corticotropin-releasing hormone) kortikotropinfelszabadító hormon; FSH = folliculusstimuláló hormon; LH = luteinizáló hormon; LST = Leydig-sejtes tumor; $\mathrm{MR}=($ magnetic resonance $)$ mágneses rezonancia; TART $=$ testicularis adrenalis rest tumor; $\mathrm{UH}=$ ultrahang

A scrotum ultrahang (UH)-vizsgálata könnyen, gyorsan, költséghatékonyan hozzáférhető eljárás, melynek során a térfoglaló folyamatok jól karakterizálhatók, továbbá a látottak a meddőségi állapothoz is fontos információt szolgáltatnak [1]. Mivel a páciensek nagy része meddőségi kivizsgálás keretében érkezik, az így felismert eltérések állítják a leginkább kihívás elé az andrológiában és UH-diagnosztikában dolgozó szakembereket. A herében lévő tumorok a fiatal, fertilis korosztályt érintik, de a meddőségi kivizsgálás során találhatunk olyan intratesticularis térfoglalást is, mely az esetek egy kis részében benignus. Ezen esetek nagy körültekintést igényelnek a megfelelő terápia megválasztása és a fertilitás biztosítása érdekében.

A jelen dolgozatban, egy eseten keresztül, több szakma szempontjából szeretnénk bemutatni a testicularis adrenalis rest tumor (TART) felismerésének és differenciáldiagnosztizálásának a buktatóit, valamint az interdiszciplináris kivizsgálásának részleteit. Az Orvosi Hetilapban egy hasonló, de más módon felderített eset ismertetését találtuk [2].

\section{Esetismertetés}

A 24 éves férfit újszülöttkora óta congenitalis adrenalis hyperplasiával $(\mathrm{CAH})$ gondozzák. Három hónappal a születése után, hányások miatt kezdődő kivizsgálás során került sor a 21-hidroxiláz enzim hiányának kimutatására, melynek következtében klasszikus sóvesztő CAH alakult

1. táblázat |A beteg laborértékei és gyógyszeres kezelése a bemutatott időszakban

\begin{tabular}{|c|c|c|c|c|c|c|c|c|c|c|}
\hline & $\begin{array}{l}\text { Gyógyszeres } \\
\text { kezelés }\end{array}$ & $\begin{array}{c}\text { 17-OH- } \\
\text { progesz- } \\
\text { teron, } \\
\mathrm{nmol} / 1 \\
(0,6-2,5)\end{array}$ & $\begin{array}{l}\text { Andro- } \\
\text { szténdion, } \\
\text { nmol/1 } \\
(2,9-9,5)\end{array}$ & $\begin{array}{c}\text { DHEA, } \\
\mathrm{nmol} / 1 \\
(8,5-36,0)\end{array}$ & $\begin{array}{c}\text { Teszto- } \\
\text { szteron, } \\
\text { nmol/1 } \\
(9,90- \\
28,00)\end{array}$ & $\begin{array}{c}\mathrm{SHBG}, \\
\mathrm{nmol} / 1 \\
(14,5- \\
48,4)\end{array}$ & $\begin{array}{c}\text { DHEA-S, } \\
\mu \mathrm{mol} / 1 \\
(5,73- \\
13,40)\end{array}$ & $\begin{array}{c}\mathrm{LH} \\
\mathrm{IU} / 1 \\
(1,7-8,6)\end{array}$ & $\begin{array}{c}\text { FSH, } \\
\text { IU } / 1 \\
(1,5-12,4)\end{array}$ & $\begin{array}{c}\text { ACTH, } \\
\mathrm{pmol} / 1 \\
(1,60- \\
13,90)\end{array}$ \\
\hline Első észlelés & $\begin{array}{l}\text { Hidrokortizon: } \\
15-10-10 \mathrm{mg} \\
\text { Fludrokortizon: } \\
0,05 \mathrm{mg}\end{array}$ & 358 & $>35$ & 4,7 & 18,71 & 37,8 & 1,60 & 4,0 & 8,5 & 91,56 \\
\hline $\begin{array}{l}\text { Terápia- } \\
\text { módosítás }\end{array}$ & $\begin{array}{l}\text { Hidrokortizon: } \\
\text { 10-5-0 mg } \\
\text { Fludrokortizon: } \\
2 \times 0,025 \mathrm{mg} \\
\text { Prednizolon: } \\
5 \mathrm{mg}\end{array}$ & 114 & 16,5 & 4,2 & 14,69 & 42,7 & 1,19 & 5,8 & 15,7 & 17,04 \\
\hline I. kontroll & $\begin{array}{l}\text { Hidrokortizon: } \\
10-5-0 \mathrm{mg} \\
\text { Fludrokortizon: } \\
2 \times 0,025 \mathrm{mg} \\
\text { Prednizolon: } \\
7,5 \mathrm{mg}\end{array}$ & $<0,3$ & - & 3,9 & 16,92 & 69,5 & & 4,4 & 10,8 & 12,07 \\
\hline II. kontroll & $\begin{array}{l}\text { Hidrokortizon: } \\
10-5-0 \mathrm{mg} \\
\text { Fludrokortizon: } \\
2 \times 0,025 \mathrm{mg} \\
\text { Prednizolon: } \\
2 \times 7,5 \mathrm{mg}\end{array}$ & $>75,0$ & $>35,0$ & 3,3 & 11,21 & 69,2 & 1,90 & 2,8 & 7,8 & 64,79 \\
\hline III. kontroll & Mütét & $>75,0$ & $>35,0$ & 4,1 & 8,66 & 62,3 & 1,51 & 5,8 & 10,5 & 16,39 \\
\hline $\begin{array}{l}\text { Mütét utáni } \\
\text { kontroll }\end{array}$ & $\begin{array}{l}\text { Hidrokortizon: } \\
10-5-0 \mathrm{mg} \\
\text { Fludrokortizon: } \\
2 \times 0,025 \mathrm{mg} \\
\text { Prednizolon: } \\
2 \times 7,5 \mathrm{mg}\end{array}$ & 12,8 & - & 4,9 & 7,03 & 45 & 0,82 & 15,5 & 15,6 & 0,92 \\
\hline
\end{tabular}

ACTH = adrenokortikotrop hormon; DHEA = dehidroepiandroszteron; DHEA-S = dehidroepiandroszteron-szulfát; FSH = folliculusstimuláló hormon; LH = luteinizáló hormon; SHBG = nemihormon-kötő globulin 
ki. A beteg a diagnózis felállítása óta folyamatos mineralo- és glükokortikoid-szteroid kezelésben részesült gyermekgyógyászaton. Kórelőzményében még adenotomia és appendectomia szerepel. A beteg gyermek- és serdülőkori kontrollvizsgálatokra rendszeresen eljárt, gyógyszerelését igény szerint módosították.

A beteget 21 éves korában irányították a felnőttendokrinológiára. Belszervi panaszt első észlelésekor, illetve a további kontrollok során sem említett, rákérdezésre szexuális diszfunkciót sem. Ekkor gyógyszeres kezelése a következő volt: reggel $15 \mathrm{mg}$, délben $10 \mathrm{mg}$, este $10 \mathrm{mg}$ hidrokortizon per os, valamint reggel $0,05 \mathrm{mg}$ fludrokortizon volt; emellett tachycardia miatt $5 \mathrm{mg}$ nebivololt is szedett. Vérvétel történt, melyből a terápia és a betegkövetés szempontjából legfontosabb értékeket táblázatos formában rögzítettük (1. táblázat). Az alap-laboreredményekből kiemelendő a normáltartományban lévő nátrium- és káliumszint: nátrium $141 \mathrm{mmol} / \mathrm{l}$ (136-145), kálium 4,3 mmol/1 (3,5-5,1). A kalcium- és parathormonszint nem mutatott eltérést, a pajzsmirigyfunkció euthyreosist igazolt, az anti-TPO a normáltartományon belül volt. A hasi, kismedencei UH-vizsgálat kórosat nem mutatott a mellékvesék területén. A magas ACTH-, 17-OH-progeszteron- és 4Dion-érték miatt gyógyszeres kezelésének módosítását javasoltuk az alábbiak szerint: 10-5-0 mg hidrokortizon per os, $2 \times 0,025 \mathrm{mg}$ fludrokortizon, este $5 \mathrm{mg}$ prednizolon per os, kiegészítve napi $600 \mathrm{mg}$ kálium-klorid per os adásával.

Ennek hatására hormonértékei a következő vizsgálat során javulást mutattak. Mind a 17-OH-progeszteron, az androszténdion és az adrenokortikotrop hormon szintje csökkent ugyan, de nem kerültek a normáltartományba. Így a csökkenő tendenciát mutató, de céltartomány feletti ACTH- és 17-OH-progeszteron-érték mi- att további gyógyszermódosítás történt: este 7,5 mg prednizolon szedését javasoltuk, egyéb gyógyszereinek meghagyásával.

A következő reguláris kontroll során eredményei jó terápiás effektust igazoltak, a vizsgálati laborértékek a normáltartományon belülre kerültek. Ezen eredmények alapján a beteg kezelését változatlanul folytattuk.

Soron következő kontrolljakor a hormonmérések a korábbiakhoz képest rosszabbul kezelt állapotot jeleztek: mind a $17-\mathrm{OH}$-progeszteron, mind a férfi-, valamint az adrenokortikotrop hormon kikerült a normáltartományból. Ezek az aktuálisan nem a céltartományban lévő eredmények - összehasonlítva a korábban céltartományban álló eredményekkel - felvetették a compliance-probléma lehetőségét is, ezért a beteg és családja ismételt részletes felvilágosítást kapott a betegségről és annak kezeléséről; emellett a prednizolon dózisát $2 \times 5 \mathrm{mg}$-ra emeltük, egyéb gyógyszereinek változatlan dózisban történő szedése mellett.

$\mathrm{Az}$ ismételt ellenőrzés során az emelt dózisú glükokortikoidkezelés ellenére az eredmények továbbra sem voltak a céltartományban.

Urológiai vizsgálatot javasoltunk, amelynek során jövőbeli fertilitási igény kivizsgálásakor azoospermia igazolódott, ezért here-UH-vizsgálat történt. Korábban hereUH-vizsgálat nem volt. Az UH-vizsgálatot GE LOGIQ S8 (General Electric, Boston, MA, Amerikai Egyesült Államok) ultrahangkészülékkel végeztük. A vizsgálat során normális mérettartományban lévő heréket észleltünk, melyeken belül inhomogén echogenitású, helyenként részben piszkos hangárnyékot adó összefüggő képlet volt látható mindkét oldalon. A képletek főként a mediastinum testist érintették (1. ábra). A jobb here felső pólusán egy, nagyjából $35 \times 25 \times 30$ mm-es, durván

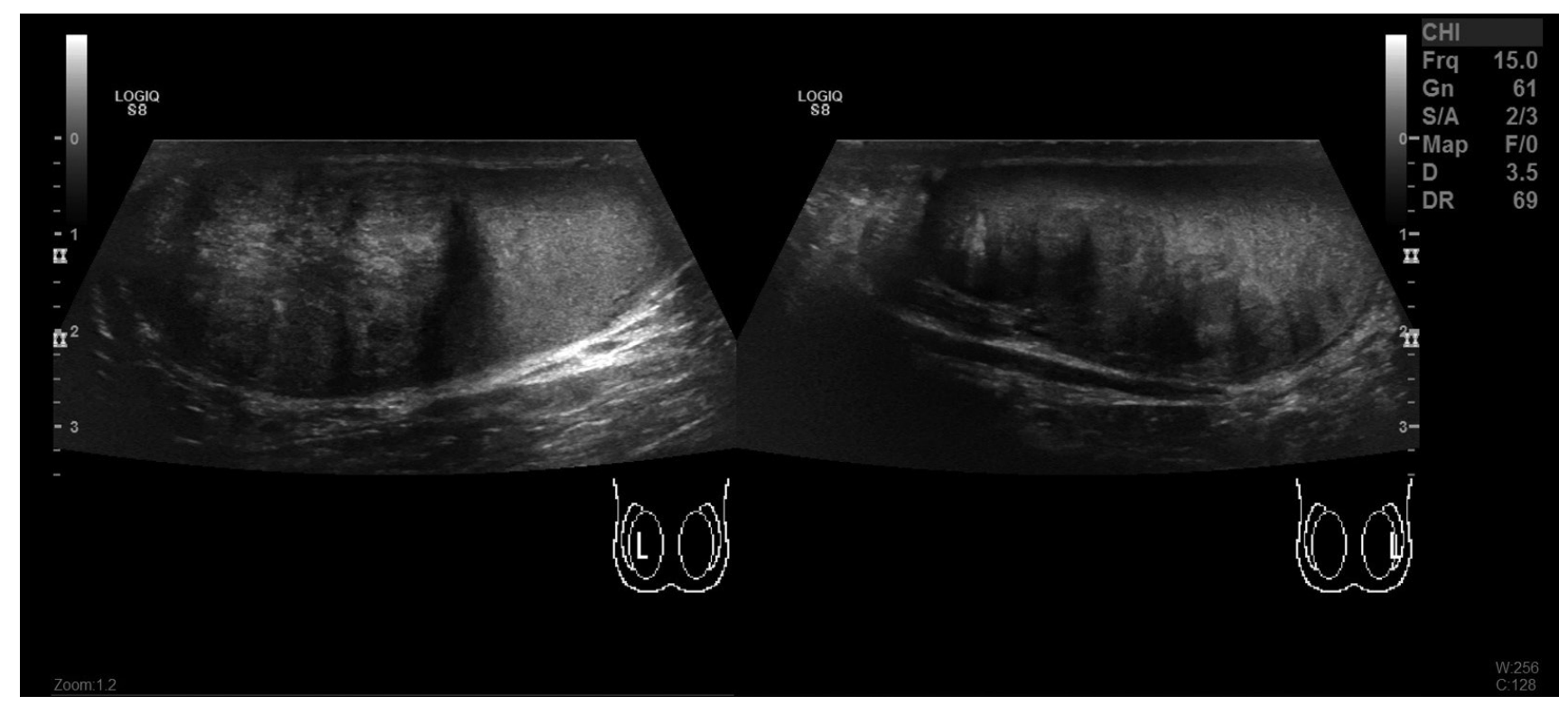

1. ábra

Az ultrahangvizsgálat lineáris (7-14 MHz) fejjel történt; jól látható a kétoldali intratesticularis térfoglalás, mely echószegényebb a környező állománynál, a jobb oldalon a here felső pólusára lokalizálódik elsősorban, bal oldalon testicularis adrenalis rest tumorra (TART) jellegzetes képet mutat, a mediastinum testisre lokalizálódik 




2. ábra

Az ultrahangvizsgálat lineáris (7-14 MHz) volt, a B-módú vizsgálatot a gyér keringés kimutatására is érzékeny 'power' Doppler-technikával egészítettük ki. Jól látható, hogy a terimében a keringés igen gyér

inhomogén terület, a bal oldalon pedig hasonló megjelenésű, $40 \times 15 \times 20$ mm-es képlet került leírásra. Doppler-vizsgálattal fokozott vascularisatio nem volt látható az elváltozásokon belül (2. ábra). Annak ellenére, hogy a herékben lévő két eltérés ultrahangos megjelenése nem volt teljesen egyforma, a radiológiai vélemény, endokrinológussal konzultálva, elsősorban a TART lehetőségét vetette fel. Testicularis és hasi-kismedencei MR- (GE Discovery MR750w 3T; General Electric) vizsgálat is történt, mely a jobb herében egy $22 \times 28 \times 31 \mathrm{~mm}$-es, T1-, T2-jel-szegény, a mediastinum testis magasságában elhelyezkedő, kissé lobulált kontúrú, éles szélü képletet jelzett, az ellenoldalon pedig egy $19 \times 39 \times 18 \mathrm{~mm}$-es, szintén a mediastinum testis mellett elhelyezkedő, hasonló megjelenésú képlet ábrázolódott (3. ábra). Meszesedésre, necrosisra utaló jelek egyik oldalon sem voltak megfigyelhetők. A hasi MR-vizsgálat során csupán a mellékvesék fokozott halmozása került leírásra, kóros nyirokcsomó vagy metastasisra típusos eltérés nem volt észlelhető. Radiológiai és urológiai konzílium történt.

Urológiai szakvizsgálat alkalmával ép külső genitáliák mellett normál nagyságú, azonban mindkét oldalon porckemény tapintatú herék voltak észlelhetők. Azoospermia miatt sebészi spermiumnyerés céljából mikro-

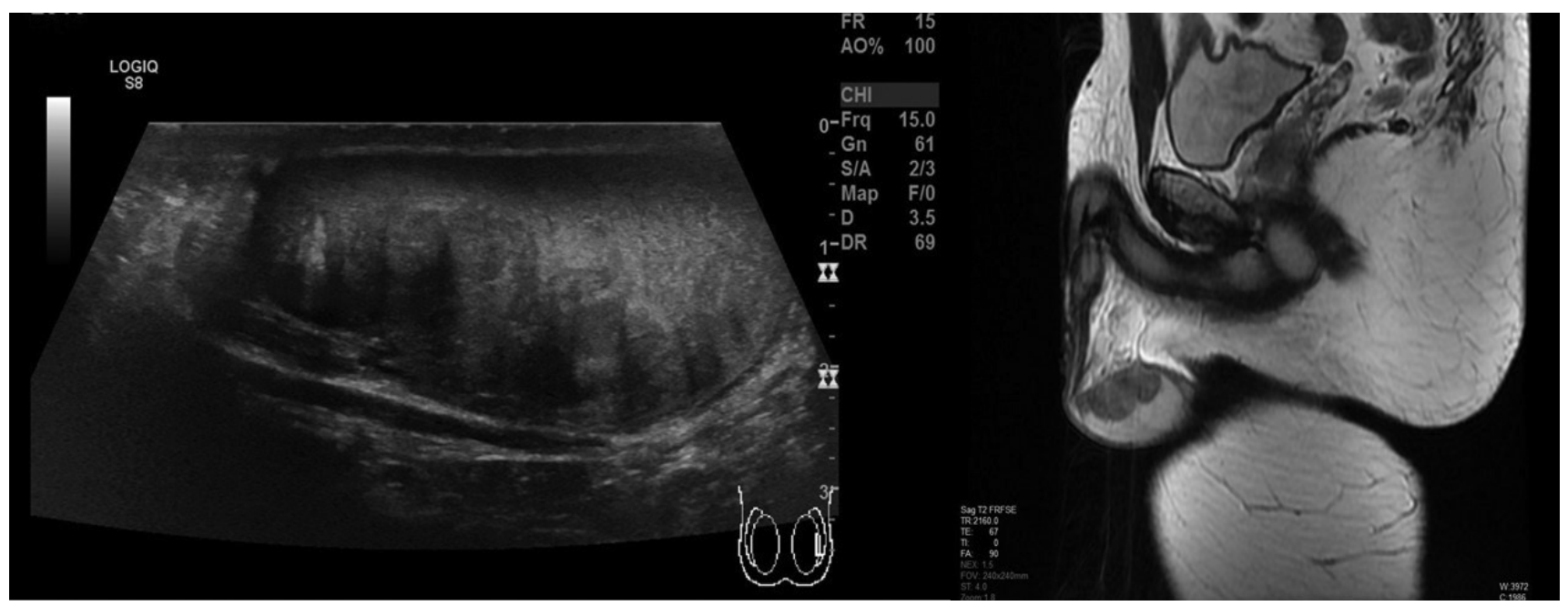

a)

3. ábra b)

Jól látható a B-módú ultrahangvizsgálat képein a bal herében a TART-ra jellegzetes térfoglalás (a). Az MRI T2-súlyozott képein jól látható a mediastinum testisben lévő jellegzetes lobulált, a hereparenchymához képest jelszegény elváltozás (b)

MRI = mágnesesrezonancia-képalkotás; TART = testicularis adrenalis rest tumor 




a)

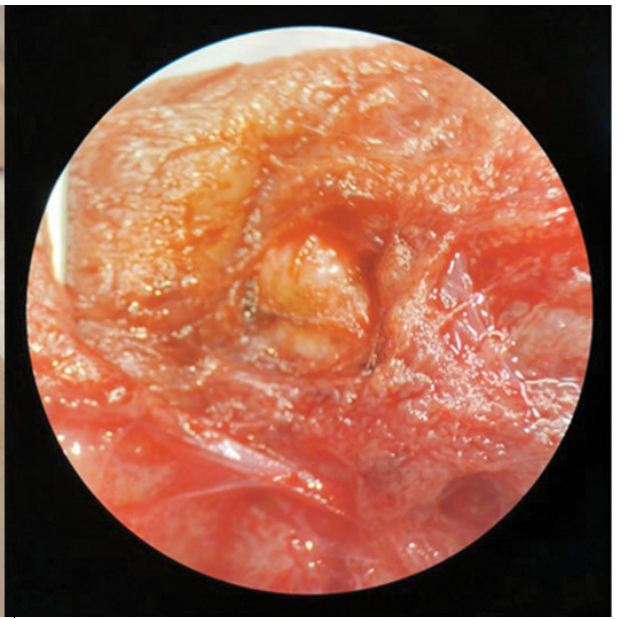

b)

4. ábra

Intraoperatívan a heretok intaktnak bizonyult. Egy szürkésfehér, porckemény szövet tűnt elő (a). Az intraoperatív mikroszkópos képen látható a vékony hereparenchyma alatt a porckemény tapintatú terime. Jelentősen tágult heretubulus nem volt megfigyelhető (b)

sebészeti herebiopsziát végeztünk, melynek kapcsán - a páciens kérését is figyelembe véve - a térfoglaló folyamatokból is történt mintavétel.

A mütét során a heretok mindkét oldalon intakt volt. A jobb herének körülbelül a kétharmadát igen tömött tapintatú terime töltötte ki, a kicsiny ép szövet alatt egy porckemény, sárga színû elváltozás tûnt elő. A bal oldalon egy hasonló morfológiájú képlet mutatkozott (4. ábra).

Az intraoperatív szövettani vizsgálat malignitást nem igazolt. A paraffinba ágyazott anyag szövettani elemzéséból kiderült, hogy a megjelenés a két mintában egyezett.

A kötőszövetes állományban egy-, illetve kétsejtes kötegeket, valamint szolid fészkeket formáló celluláris proliferáció volt kivehető. A laesionalis sejtek kicsik voltak,

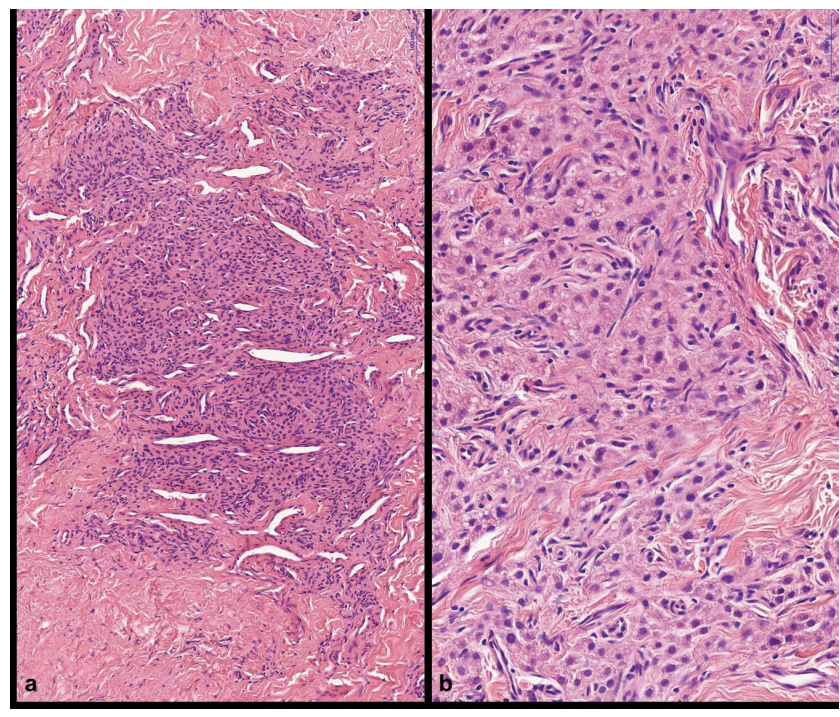

5. ábra

Kötegekbe, illetve szolid fészkekbe rendeződő sejtszaporulat, melynek környezetében kifejezett fokú kötőszövet-képződés észlelhető (hematoxilin-eozin festés, 100x-os nagyítás) (a). A laesionalis sejtek kicsik, a citoplazma vakuolizált. A citológiai atípia minimális, sejtosztódás vagy Reinke-kristály nem látható (hematoxilin-eozin festés, 400×-os nagyítás) (b) citoplazmájuk eozinofil, melyben helyenként lipidcseppek voltak megfigyelhetők. Reinke-kristályok nem ábrázolódtak. A citológiai atípia alacsonynak bizonyult, sejtosztódás nem volt jelen (5. ábra). Immunhisztokémiailag a sejtek diffúz CD56- és MelanA-pozitivitást, valamint részleges szinaptofizin- és androgénreceptor-pozitivitást mutattak. A látottak alapján a patológus a laesiót TARTnak véleményezte. A környező hereállományban súlyos parenchymakárosodás állt fenn. Ép spermogenezis sem a tumor mellett, sem pedig attól távolabb nem volt jelen. A tubulusok jórészt hialinizálódtak, egy-egy tubulusban pedig csupán Sertoli-sejtek voltak jelen (Johnsen-score 4/10) (6. ábra). Ez a szöveti megjelenés lényegében összhangban állt az obstruktív azoospermia klinikai diagnózisával. A beavatkozás során ép hímivarsejtet nem sikerült izolálni.

A beteg további endokrinológiai kezelése, valamint rendszeres képalkotó vizsgálattal történő követése folyamatban van.

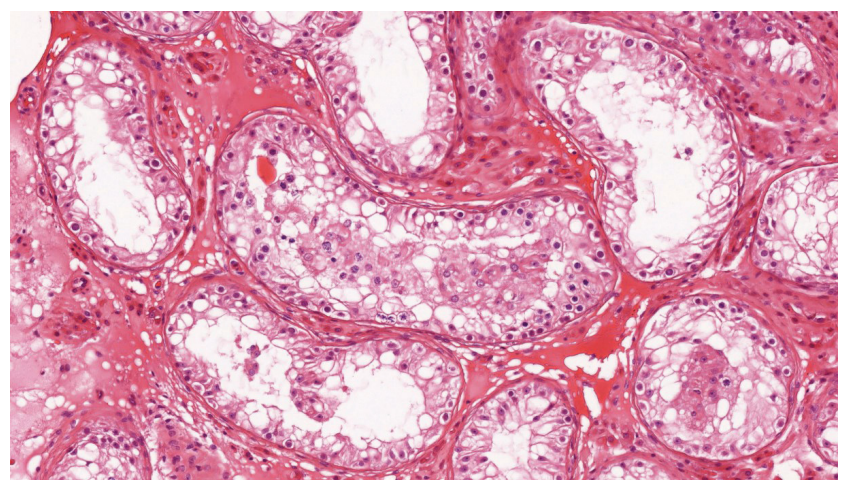

6. ábra

A herecsatornák jó részében csupán spermatogoniumok és Leydig-sejtek látszanak. Elvétve korai spermiocyták még jelen vannak, de kiérő spermiogenezis nem észlelhetô. Az intersztíciumban kötőszövet-felszaporodás és enyhe fokú Leydig-sejthyperplasia figyelhető meg (hematoxilin-eozin festés, $200 \times$-os nagyítás) 
Posztoperatív hormonális eredményei változatlan gyógyszeres kezelés mellett jó kezelési eredményt mutattak, így gyógyszeres kezelését továbbra is változatlanul javasoltuk folytatni.

\section{Endokrinológiai háttér}

A 21-hidroxiláz-deficientia az egyik leggyakoribb monogénes anyagcsere-betegség, melynek magyarországi gyakorisága 1 : 14000 [3].

A CAH autoszomális recesszív módon öröklődő betegségek összefogaló neve, melyeket a mellékvese szteroidhormon-szintézisének zavara jellemez. A különböző megjelenési formákban a mineralo-, glükokortikoid-, valamint a szexuálszteroidok bioszintézise károsodott. A 21-hidroxiláz enzim a mellékvesekéreg sejtjeinek sima felszínű endoplazmatikus reticulumában katalizálja a progeszteron és a 17- $\alpha$-hidroxi-progeszteron hidroxilálását. A 21-hidroxiláz enzim defektusának következtében nem termelődik elég kortizol, ami miatt a hypothalamusban, valamint a hypophysisben fokozódik a kortikotropinfelszabadító hormon (CRH) és az adrenokortikotrop hormon (ACTH) termelése. Ennek hatására egyrészt CAH alakul ki, másrészt pedig a szteroidszintézis az androgének és ösztrogének felé tolódik. A megváltozott hormontermelés következménye a lánygyermekek virilisatiója, valamint a mindkét nemben megfigyelhető felgyorsult növekedés és csontosodás (klasszikus virilisatiós forma). Az enzimdefektus miatt az aldoszteron szintézise is csökken, ami a betegek mintegy $75 \%$ ában sóvesztéshez vezet (klasszikus sóvesztő forma), és korai, súlyos hyponatraemiás hypovolaemia kialakulását okozhatja. A 21-hidroxiláz enzim defektusának enyhébb formájában (nem klasszikus forma) a kortizol és az aldoszteron szintézise normális tartományban van, az androgének szintje azonban kissé emelkedett. Ezek a betegek enyhébb tünetekkel jelentkezhetnek, mint például pubertas praecox, akné vagy fertilitási problémák [4].

A férfi CAH-betegek körében infertilitás alakulhat ki, melynek oka kettős: egyrészt a hypogonadismus, másrészt a TART megjelenése, mely gyakori szövődménynek számít [3]. A TART kialakulásának patomechanizmusa nem teljesen ismert, feltehetőleg a magzati fejlődés során a here állományába került adrenocorticalis sejtekből alakul ki. Mivel a tumorok térfogata nagy dózisú kortikoszteroidkezelésre általában csökken, valamint megjelenésének idején az ACTH-szint emelkedett, az valószínüsíthető, hogy a magas szérum-ACTH-szint és luteinizálóhormon-hatás felelős a kialakulásukért. Egyes tanulmányok szerint a tumorsejteken ACTH-receptorok is megfigyelhetők, ami megerősíti, hogy embrionális korban mellékvese-eredetű sejtcsoportok szálltak le a herékkel együtt $[5,6]$. A TART jellemzően a mediastinum testis területén jelenik meg, eredendően nem malignus, a mediastinum területén azonban fibrosist indukál, majd pedig obstruktív azoospermiához és meddőséghez vezet.

\section{Patológiai vonatkozások}

A TART elkülönítése a here csírasejtes tumoraitól, a lymphomától vagy a lágyrész-daganatoktól nem okoz diagnosztikai nehézséget, a TART differenciáldiagnosztikájában viszont a legfontosabb entitás a Leydig-sejtes tumor (LST). A TART-ot felépítő sejtek egyszerre hordozzák a mellékvesekéreg és a Leydig-sejtek jellemvonásait, ami arra utal, hogy ezek a sejtek totipotens embrionális őssejt eredetűek lehetnek [7]. Az LST-knek csupán a 3\%-a bilaterális, ezzel szemben TART esetén a kétoldaliság 83\%-os. Míg az előbbi tumorok 10\%-a rosszindulatú, ezzel szemben az utóbbiak mindig jóindulatúak. Itt fontos hangsúlyozni, hogy a TART a neve ellenére hiperplasztikus folyamatnak és inkább pszeudotumornak tekintendő, az LST viszont valódi neoplasiának felel meg. A két daganatféleség makroszkóposan is különbözik, a TART ugyanis jellemzően egygócú, fekete laesióként látható a here állományában, míg az LST gyakran többgócú, sárga tumorok képében jelentkezik. Jelentős fokú fibrosis, zsírszöveti metaplasia, lymphoid sejtes aggregátumok, emelkedett citológiai atípia és kifejezett lipokrómpigment-felhalmozódás gyakran megfigyelhető jelenségek TART esetén [8]. Továbbá az ilyen tumorokban sejtosztódások egyáltalán nem vagy csak hosszas keresgélés után fedezhetők fel, jóllehet ezek az LST-esetek 69\%-ában jelen vannak. Habár a Reinke-kristályokról úgy tartják, hogy patognomikusak a Leydig-sejtekre, ez a jellegzetesség az LST-knek csupán a 40\%-ában mutatható ki, és a TART-okban sosincs jelen, tehát a Reinke-kristályok hiánya önmagában nem segíti a helyes diagnózis felállítását $[6,8]$. Immunhisztokémiailag a legfontosabb marker a szinaptofizin, mely a TART-esetek $88 \%$-ában erős pozitív reakciót ad, ezzel szemben az LST-knek csupán a 8\%-ában figyelhető meg hasonló intenzitású pozitivitás. További fontos marker még a CD56, mely jellemzően pozitív a neuroendokrin tumorokban, továbbá az androgénreceptor (AR), mely az előbbi daganat kapcsán általában negatív, az utóbbiban viszont pozitív reakciót ad. Nem segíti viszont a két entitás elkülönítését az inhibin- $\alpha$, ez ugyanis mindkét tumorban expresszálódik. Az evidenciák alapján a klinikai adatok, a hormonszintek és a szövettani jellegzetességek mellett a szinaptofizint, CD56-ot és AR-t tartalmazó immunhisztokémiai panel segíti a helyes diagnózis felállítását [9]. A környező hereállomány a folyamat kiterjedtségétől függően károsodott, a spermiogenezis kezdetben kismértékben, majd pedig fokozatosan csökken. Előrehaladott esetekben csupán hialinizálódott vagy csak Sertoli-sejteket tartalmazó tubulusok vehetők ki a peritumoralis hereparenchymában. A spermiogramban a folyamat súlyosságától függően oligospermia vagy azoospermia észlelhető. A TART és az LST közötti hasonlóságokat és különbségeket Wang és mtsai foglalták össze [10]. 


\section{Képalkotás - differenciáldiagnosztika}

A herék térfoglaló folyamatai között a kétoldaliság gyakorisága igen változatos megoszlást mutat. Gyermekkorban az akut lymphoblastos leukaemia az esetek 5\%-ában okozhat kétoldali eltérést [11]. Az elsősorban a fiatal populációt érintő, csírasejtes tumorok ritkán (1,8\%-ban) válnak kétoldalivá [12]. Az idősebb populációban a csírasejtes tumoroknál ritkábban előforduló lymphoma vagy az áttétek lehetnek kétoldaliak. A testicularis lymphoma a csírasejtes tumorokhoz képest sokkal ritkábban fordul elö [13]. Hereáttétek ismert tumoros betegekben nagyon ritkán, csupán 0,04\%-ban fordulnak elő a herében, leggyakrabban a prosztatarák (35\%), amelyet a tüdő-, a vese- és a vastagbélrák, valamint a melanoma malignum előrehaladott stádiumban adott áttétei követnek. A metastasisok megjelenési gyakorisága 55 éves életkorra tehető. Az áttétek terjedése a lymphovascularis rendszeren keresztül történik, de a vese-, illetve a prosztatarák áttéteinek kialakulásában fontos szerepe van a plexus pampiniformisban lévő vénatágulatnak és a vénás elégtelenség miatt kialakult 'reverse flow'-nak is. A ritkán előforduló intratesticularis metastasis fö feltételezett oka a vér-here-gát védőhatása, más régebbi elképzelések szerint a herében lévő alacsonyabb hőmérséklet sem kedvez a daganatszövet növekedésének [14]. A korábbi térfoglaló folyamatokkal szemben a TART jellemzően kétoldali elváltozást okoz.

A TART diagnózisának felállításában az UH és az MR képalkotó vizsgálatok nyújthatnak segítséget. Az elsődleges szerep a jó elérhetőség és a költséghatékonyság miatt az UH-vizsgálatoké.

A herék UH-vizsgálatának diagnosztikus hasznát már az 1970-es évektől kezdődően kutatták. 1977-ben Miskin az akkoriban csúcstechnológiás, 5 MHz-es transzducerrel végzett here-UH-vizsgálatok klinikai hasznát emelte ki [15]. A technika rohamosan fejlődött, és néhány éven belül megjelent az első közlemény, mely az UH-vizsgálatoknak a TART diagnózisában és követésében betöltött szerepéról szólt [16]. A szerzők szerint a CAH- és a primer mellékvese-elégtelenségben szenvedő betegek körében a herékben bilaterálisan, excentrikusan elhelyezkedő nodulusok - melyekben esetlegesen akusztikus árnyékolás is megfigyelhető - elsősorban TART-nak véleményezhetők.

A TART ultrahangos megjelenése viszonylag típusos: a kezdeti stádiumban kis, multifokális, a környező hereparenchymához viszonyítva echószegény képletek jelennek meg a mediastinum testis területén; később ezek, összeolvadva, nagyobb echószegény területet képeznek, melyben hiperreflektív területek is lehetnek [17]. Az echódús megjelenés ritka. Éles szegélyü, lobulált, a here kontúrjait viszonylag kevéssé torzítja, rajta előboltosulást nem okoz. Differenciáldiagnosztikai kihívást jelent elkülöníteni a nem csírasejtes tumoroktól, úgymint a Leydigsejtes vagy a Sertoli-sejtes tumortól. Fontos támpont lehet, hogy a TART általában nem tartalmaz necrosist, bevérzést vagy meszesedést, továbbá a mediastinum testis mentén helyezkedik el [18]. Erezettsége a környezeténél kissé csökkentebb. A lymphomától való elkülönítésben nagyon fontos a color-Doppler-módban végzett vizsgálat, mivel a lymphoma vascularisatiója a környezeténél fokozottabb, valamint a lymphoma ezen megjelenése elsősorban nem a fiatal korosztályra jellemző megbetegedés. A primer testicularis lymphoma a nonHodgkin-lymphomának egy viszonylag ritka formája, amelynél az átlagéletkor 66-68 év; a here malignus megbetegedéseinek kevesebb mint 5\%-át teszi ki. A TARTnál ritkábban, csupán 6-10\%-a kétoldali [13].

A differenciáldiagnózis megkönnyítésére Nuffer és mtsai döntési folyamatot dolgoztak ki. Ha az anemnesztikus adatok alapján felmerül a TART, az UH-képen típusos lokalizációban echószegény, lobulált eltérés azonosítható akkor egyoldaliság esetén elsősorban a meszesedés jelenlétét kell kizárni, valamint a kontúrok megjelenését kell jól megítélni. Amennyiben a kontúrok elmosódottak, vagy a vizsgált eltérésben meszesedés észlelhető, felmerül a tumoros eredet. Kétoldali eltérés esetén különösen figyelni kell a fokozott vascularisatióra, mely lymphomát jelezhet. A TART ultrahangos megjelenése a környező hereparenchymánál gyérebb vascularisatiót mutat [18].

A TART-betegek MR-vizsgálatáról már a 2000-es évek előtt is jelentek meg cikkek, melyek leírták, hogy a TART a Tl-szekvenciákon a normális hereállományhoz képest izo/hiperintenzív, a T2-szekvenciákon azonban hipointenzív megjelenésü $[19,20]$. Az elváltozás mindkét alapszekvencián homogén, tokkal nem határolt. Kontrasztanyag adása után az esetek $85 \%$-ában volt megfigyelhető halmozás. Egy másik tanulmány szerint az összes TART homogén kontrasztanyag-halmozást mutat [21]. A cikkek szerzői egyetértenek abban, hogy az MRvizsgálat (az alapszekvenciákat figyelembe véve) és az UH-vizsgálat diagnosztikus értéke megegyezik. Amenynyiben egy beteg esetében szóba jön a részleges orchiectomia, úgy az MR-vizsgálat már indokolttá válhat, mivel ez a mútéti tervezést segíti. Az eddig megjelent cikkek leginkább az alap-MR-szekvenciákat tanulmányozták TART esetében. Az MR-spektroszkópia hasznos lehet a hereállomány funkciójának megítélésében, mivel károsodott here esetében a colin csúcs csökkenést mutat, már a morfológiai elváltozások megjelenése előtt $[22,23]$.

\section{Urológiai-andrológiai szempontok}

A CAH az infertilitás gyakori okozója. A testicularis adrenalis rest tumorok megjelenése jól ismert jelenség, és fontos komplikációnak számít, amely a betegek kb. 3094\%-ában alakul ki. Tipikus megjelenési helye a mediastinum testis, ami miatt a heretubulusok elzáródhatnak, emellett az elváltozás a környező szövetek tartós károsodását okozza, ami következményes azoospermiához, így infertilitáshoz vezet [24]. A mechanikus obstrukció/ destrukció mellett a mellékvesekéreg-szteroidhormonok 
és azok metabolitjainak lokális toxikus hatása is hozzájárul a Sertoli- és/vagy a csírasejtek károsodásához [24, 25]. A nagy mennyiségben termelődő androgének pedig az LH és az FSH szuppresszióján keresztül tovább ronthatják a fertilitást [2].

Korai stádiumban a daganattól távolabb lévő hereparenchymából nyert szövettani minta még sok esetben nem mutat eltérést. Ennek lehetséges magyarázata a károsodás progresszív volta, mely a tumor körüli szövetekben kezdődik, és a távolabbi területek csak később válnak érintetté. Ez alapján érthető, hogy nemcsak a daganatok lokalizációja, hanem azok mérete, illetve az obstrukció időtartama is fontos tényező a gonadális diszfunkció kialakulása szempontjából [26]. Az elváltozás növekedésével a herében irreverzibilis károsodás alakul ki, mely az endokrin és az exokrin funkciót egyaránt érinti [24, 27].

Számos tanulmány igazolta, hogy az elváltozások kimutatására here-UH-vizsgálat elvégzése a legalkalmasabb, mivel ezzel a még nem tapintható $(<2 \mathrm{~cm})$ laesiók is jól detektálhatók [24].

Claabsen-van der Grinten és munkacsoportja a TART-ot 5 stádiumba sorolja, figyelembe véve a klinikai és a szövettani megjelenést, valamint a tumor növekedését. $\mathrm{Az}$ első stádiumban az elváltozás képalkotással még nem mutatható ki, az adrenalis rest sejtek a rete testis területén helyezkednek el. Az UH-vizsgálatnak a második stádiumtól van jelentôsége, amelynél a TART már kimutatható, a mediastinum testis területén elhelyezkedő kicsi, echószegény elváltozás formájában. A harmadik stádiumtól a rete testis fokozatos kompressziója alakul ki, melyhez a négyes stádiumban már fibrosis társul. Az ötödik stádiumban megjelenik a hereparenchyma károsodása a tömeges TART mellett [27].

A TART kezelését illetően a korai stádiumban végzett nagy dózisú hormonkezelés vagy a mütéti kezelés csökkenti a tumor méretét, eliminálja az obstrukciót, megelőzheti a további károsodást. Jóllehet a mútétet követően a TART kiújulását nem figyelték meg, a beavatkozás a már kialakult károsodást nem javítja [2, 26, 28].

Azon betegeknél, akiknél a kétoldali TART hosszú ideje fennáll, a szervmegtartó sebészi kezelésnek nincs hatása a gonadális funkcióra, a spermaparaméterekben sem találtak javulást, továbbá a mútét okozta további károsodások veszélye sem zárható ki [24, 25, 27]. Ezért ezekben az esetekben a sebészi kezelés már csak fájdalom és a diszkomfort csökkentése céljából indokolt [27].

A fertilitási ráta igen alacsony. Korai stádiumban, a tumor eltávolításával egy ülésben végzett sebészi spermiumnyerés, illetve az intracitoplazmatikus spermiuminjekció lehetséges megoldást jelent [24, 26, 28$]$.

A fertilitás biztosítása és a további irreverzibilis herekárosodás megelőzése céljából a minél korábban, a pubertás kezdetén, illetve a pubertáskorban végzett hereUH-vizsgálat, a sebészi spermiumnyerés és a páciensek szoros követése elengedhetetlen.

\section{Megbeszélés}

A here térfoglaló folyamatainak hátterében döntően urológiai megbetegedések állnak, így a kivizsgálás és a kezelési terv is döntően urológiai szemléletet tükröz. Olyan esetekben viszont, amikor szisztémás társbetegség is fennáll, a multidiszciplináris megközelítés megkerülhetetlen.

A 21 -hidroxiláz-deficientia az egyik leggyakoribb monogénes anyagcsere-betegség; férfi betegek esetében infertilitás elsősorban TART jelenléte, gonadotropinszuppresszió és herekárosodás miatt jöhet létre. Mivel a TART előfordulása CAH-ban 10 éves kor után növekszik, fontos a páciensek rendszeres, 1-2 évenkénti ultrahangos szûrése. A TART már a második stádiumtól könnyen jól elkülöníthető a mediastinum testis területén látható kicsi, jól körülhatárolt, echószegény eltérésként, mely gyakran kétoldali. Az időben megkezdett glükokortikoidkezeléssel, valamint az ACTH-szintek szuppressziójával a TART volumene jelentősen csökkenthető, kialakulása megelőzhető, így a fertilitás megtartható. Amennyiben a TART nem reagál a terápiára, a termékenység megtartására a spermiumnyerés és -tárolás megfontolandó [29]. Amennyiben a TART felfedezése a fiatal felnőtt korra tolódik ki, fontos a pontos differenciáldiagnózis, hogy a beteget a feleslegesen végzett szemikasztrációtól megóvjuk, amennyiben pedig azoospermia igazolódik, mielőbbi mikrosebészeti herebiopszia elvégzése javasolt a sikeres gyermekvállalás reményében. A sikeres kezelés az endokrinológus, a képalkotást végző szakember, a patológus és az urológus/andrológus szoros együttmúködésén és a jó kommunikáción múlik.

Anyagi támogatás: A közlemény megírása anyagi támogatásban nem részesült.

Szerzői munkamegosztás: B. Á.: A vizsgálati szempontok kidolgozása a képalkotás szemszögéből, szakirodalmi másodelemzés, adatgyưjtés, a kézirat szövegezése. K. L.: A vizsgálati szempontok kidolgozása a patológus szemszögéből, szakirodalmi másodelemzés, adatgyújtés, a kézirat szövegezése. H. E.: A vizsgálati szempontok kidolgozása az urológus szemszögéből, szakirodalmi másodelemzés, adatgyújtés, a kézirat szövegezése. M. S.: A vizsgálati szempontok kidolgozása az endokrinológus szemszögéből, szakirodalmi másodelemzés, adatgyüjtés, a kézirat szövegezése. K. Zs. T.: A kézirat szövegezése. Sz. A., Sz. E.: A kézirat szövegezése, rendszerezés, szakirodalmi másodelemzés. K. I. E.: Az andrológiai szempontok bemutatása, szakirodalmi elemzés. P. A., F. Zs.: A kézirat szövegezése. A cikk végleges változatát valamennyi szerző elolvasta és jóváhagyta.

Érdekeltségek: A szerzőknek nincsenek érdekeltségeik. 


\section{Irodalom}

[1] Fejes Zs, Pásztor N, Karczagi L. The role of ultrasonography in the investigation of male infertility. [Az ultrahangmódszerek szerepe a férfimeddőség kivizsgálásában.] Orv Hetil. 2018; 159: 815-822. [Hungarian]

[2] Vajda Zs, Borbély G, Jakab Zs, et al. Bilateral testicular tumors in a young male with congenital $11 \beta$-hydroxilase deficiency. [11- $\beta$-hidroxiláz enzim defektusában szenvedő fiatal férfi kétoldali heredaganata.] Orv Hetil. 2010; 151: 1863-1868. [Hungarian]

[3] Doleschall M, Török D, Mészáros K, et al. Steroid 21-hydroxylase deficiency, the most frequent cause of congenital adrenal hyperplasia. [Szteroid-21-hidroxiláz-deficiencia, a congenitalis adrenalis hyperplasia leggyakoribb oka.] Orv Hetil. 2018; 159: 269-277. [Hungarian]

[4] White PC, Speiser PW. Congenital adrenal hyperplasia due to 21-hydroxylase deficiency. Endocr Rev. 2000; 21: 245-291. [Correction: Endocr Rev. 2000; 21: 550.]

[5] Giacaglia LR, Mendonca BB, Madureira G, et al. Adrenal nodules in patients with congenital adrenal hyperplasia due to 21 -hydroxylase deficiency: regression after adequate hormonal control. J Pediatr Endocrinol Metab. 2001; 14: 415-419.

[6] Bonaccorsi AC, Adler I, Figueiredo JG. Male infertility due to congenital adrenal hyperplasia: testicular biopsy findings, hormonal evaluation, and therapeutic results in three patients. Fertil Steril. 1987; 47: 664-670.

[7] Smeets EE, Span PN, van Herwaarden AE, et al. Molecular characterization of testicular adrenal rest tumors in congenital adrenal hyperplasia: lesions with both adrenocortical and Leydig cell features. J Clin Endocrinol Metab. 2005; 100: E524-E530.

[8] Ashley RA, McGee SM, Isotaolo PA, et al. Clinical and pathological features associated with the testicular tumor of the adrenogenital syndrome. J Urol. 2007; 177: 546-549.

[9] Naouar S, Braiek S, El Kamel R. Testicular tumors of adrenogenital syndrome: from physiopathology to therapy. Presse Med. 2017; 46: 572-578.

[10] Wang Z, Yang S, Shi H, et al. Histopathological and immunophenotypic features of testicular tumour of the adrenogenital syndrome. Histopathology 2011; 58: 1013-1018.

[11] Gutjahr P, Humpl T. Testicular lymphoblastic leukemia/lymphoma. World J Urol. 1995; 13: 230-232.

[12] Zequi Sde C, Da Costa WH, Santana TB, et al. Bilateral testicular germ cell tumours: a systematic review. BJU Int. 2012; 110: 1102-1109.

[13] Cheah CY, Wirth A, Seymour JF. Primary testicular lymphoma. Blood 2014; 123: 486-493.

[14] Bart J, Groen, HJ, van der Graaf WT, et al. An oncological view on the blood-testis barrier. Lancet Oncol. 2002; 3: 357-363.

[15] Miskin M, Buckspan M, Bain J. Ultrasonographic examination of scrotal masses. J Urol. 1977; 117: 185-188.
[16] Seidenwurm D, Smathers RL, Kan P, et al. Intratesticular adrenal rests diagnosed by ultrasound. Radiology $1985 ; 155$ : 479-481.

[17] Stikkelbroeck NM, Suliman HM, Otten BJ, et al. Testicular adrenal rest tumours in postpubertal males with congenital adrenal hyperplasia: sonographic and MR features. Eur Radiol. 2003; 13: 1597-1603.

[18] Nuffer Z, Lu M, Jefferson, et al. Sonographic spectrum of testicular adrenal rest tumors. Am J Sonogr. 2018; 1: 1-4.

[19] Walker BR, Skoog SJ, Winslow BH, et al. Testis sparing surgery for steroid unresponsive testicular tumors of the adrenogenital syndrome. J Urol. 1997; 157: 1460-1463.

[20] Avila NA, Premkumar A, Merke DP. Testicular adrenal rest tissue in congenital adrenal hyperplasia: comparison of MR imaging and sonographic findings. Am J Roentgenol. 1999; 172: 10031006.

[21] Yilmaz R, Şahin D, Aghayev A, et al. Sonography and magnetic resonance imaging characteristics of testicular adrenal rest tumors. Pol J Radiol. 2017; 82: 583-588.

[22] Ozisik, H, Yurekli SB, Simsir YI, et al. Testicular adrenal rest tumor (TART) in congenital adrenal hyperplasia. Eur J Med Genet. 2017; 60: 489-493.

[23] Parenti GC, Albarello F, Campioni P. Role of MR spectroscopy (HI-MRS) of the testis in men with semen analysis altered. Reprod Syst Sex Disord. 2016; 5: 182.

[24] Dumic M, Duspara V, Grubic Z, et al. Testicular adrenal rest tumors in congenital adrenal hyperplasia - cross-sectional study of 51 Croatian male patients. Eur J Pediatr. 2017; 176: 13931404 .

[25] Sha YK, Sha YW, Ding L, et al. A case of bilateral testicular tumors subsequently diagnosed as congenital adrenal hyperplasia due to 21-hydroxylase deficiency. Int J Fertil Steril. 2016; 9: 574-580.

[26] Claahsen-van der Grinten HL, Otten BJ, Hermus AR, et al. Testicular adrenal rest tumors in patients with congenital adrenal hyperplasia can cause severe testicular damage. Fertil Steril. 2008; 89: 597-601.

[27] Claahsen-van der Grinten HL, Hermus AR, Otten BJ. Testicular adrenal rest tumours in congenital adrenal hyperplasia. Int $\mathrm{J}$ Pediatr Endocrinol. 2009; 2009: 624823.

[28] El-Maouche D, Arlt W, Merke DP. Congenital adrenal hyperplasia: the Lancet seminar series. Lancet 2017; 390: 2194-2210.

[29] Speiser PW, Arlt W, Auchus RJ, et al. Congenital adrenal hyperplasia due to steroid 21-hydroxylase deficiency: an Endocrine Society Clinical Practice Guideline. J Clin Endocrinol Metab. 2018; 103: 4043-4088. [Correction: J Clin Endocrinol Metab. 2019; 104: 39-40.]

(Fejes Zsuzsanna dr., Szeged, Semmelweis u. 6/A, 6725 e-mail: dr.fejes.zsuzsanna@gmail.com)

A cikk a Creative Commons Attribution 4.0 International License (https://creativecommons.org/licenses/by/4.0/) feltételei szerint publikált Open Access közlemény, melynek szellemében a cikk bármilyen médiumban szabadon felhasználható, megosztható és újraközölhetö, feltéve, hogy az eredeti szerző és a közlés helye, illetve a CC License linkje és az esetlegesen végrehajtott módosítások feltüntetésre kerülnek. (SID_1) 